\title{
Belajar Bahasa Inggris Berdasarkan "Inquiry Project" bagi Mahasiswa Vokasi di Politeknik Pertanian Negeri Samarinda
}

\author{
Suswanto* \\ Teknologi Rekayasa Perangkat \\ Lunak, Politeknik Pertanian Negeri \\ Samarind, Samarinda, 75131 \\ suswanto.attala@gmail.com \\ *Corresponding author
}

\author{
Budi Rachmadani \\ Pengelolaan Perkebunan, Politeknik \\ Pertanian Negeri Samarind, \\ Samarinda, 75131 \\ budi.rdani@gmail.com
}

\author{
Puspita \\ Pengelolaan Perkebunan, Politeknik \\ Pertanian Negeri Samarind, \\ Samarinda, 75131 \\ puspita@politanisamarinda.ac.id
}

\begin{abstract}
Abstrak-Penelitian ini bertujuan untuk menggambarkan dan memaknai inquiry project dalam proses perkuliahan pada program studi diploma tiga dan empat Politeknik Pertanian Negeri Samarinda yang bersifat inquiry. Jenis penelitian ini adalah penelitian kualitatif fenomenologi. Informan dalam penelitian ini adalah dosen mata kuliah Bahasa Inggris, staf administrasi pada program studi, pustakawan, mahasiswa. Semua informan tersebut merupakan sumber data primer yang berkenaan dengan proses kegiatan perkuliahan yang inquiry project. Data dikumpulkan dengan mengunakan pengamatan nonpartisipan, wawancara mendalam, dan dokumentasi. Penelitian ini menggunakan dua model analisis yaitu analisis saat mempertajam keabsahan data dan analisis melalui interpretasi data secara keseluruhan. Dalam hal ini ada empat tahap penting yang sangat berkaitan, yaitu: pengumpulan data, reduksi data, penyajian data dan penarikan kesimpulan atau verifikasi. Hasil penelitian menunjukkan bahwa proses pembelajaran yang bersifat inquiry project dapat ditemukan pada : demokratisasi di dalam proses perkuliahan praktek, kebebasan mahasiswa dalam mengembangkan potensinya, dan memelihara hubungan (care ralation) antara dosen dengan mahasiswa.
\end{abstract}

Kata Kunci-Learning English, inquiry project, vocational students

\section{PENDAhuluan}

Pelaksanaan perkuliahan yang sudah berjalan saat ini pada lembaga tinggi formal khususnya di POLITANI Samarinda masih memiliki kecenderungan kurang memberi bentuk kebebasan pada mahasiswa dalam berekplorasi mengembangkan potensi yang ada pada diri mahasiswa. Mahasiswa kurang mendapat kesempatan untuk menyampaikan pendapat yang berbeda. Mahasiswa belajar dalam ruang kelas yang terancang dalam situasi yang tersetruktur, yang terfokus pada latihan-latihan soal yang berbentuk essay berstruktur bahkan dalam bentuk pilihan ganda (multiple-choice test). Proses kegiatan perkuliahan masih belum konsisten dengan mahasiswa belajar aktif/berpusat pada mahasiswa/ learners yang mendasarkan pada prinsip kebebasan dalam pendidikan digambarkan dalam prinsip progresivesm, melalui prinsip progresivisme peran dari pada dosen berfokus pada keterlibatan aktif mahasiswa dan aspek perkuliahan demokratis dan co-operatif.

Dalam kegiatan belajar di kampus mahasiswa mengritik pendapat dosen termasuk "kurang etis", karena pendapat dosen adalah selalu betul. Kelas diatur sedemikian ketat, sehingga tidak memungkinkan munculnya ide dan kreatifitas mahasiswa (Zamroni, 2001, p.45). Dosen tidak akan berani membawa isu-isu yang hangat dan sensitif yang ada di masyarakat. Apa yang dipelajari kebanyakan hanya ada di buku teks, terutama yang menyangkut ideology negara seakan-akan merupakan sabda Tuhan yang tidak baik untuk dibantah dan dikritik. Sistem perkuliahan seperti ini menjadikan mahasiswa sebagai manusia-manusia yang terasing dan tercabut dari realitas sekitarnya, karena dosen telah mendidik mereka menjadi orang lain dan bukan menjadi dirinya sendiri. Akhirnya pendidikan dalam perkuliahan bukan menjadi sarana untuk menumbuhkembangkan potensi-potensi mahasiswa akan tetapi malah menjadikan mereka sebagai manusia-manusia yang disiapkan untuk kepentingan tertentu. Lebih ironis, ketika pendidikan dalam perkuliahan dijadikan sebagai sarana terbaik untuk memelihara keberlangsungan politik status quo, bukan sebagai kekuatan penggugah (Mansour, 2001, p.42).

Banyak kritik terhadap kecederungan perkuliahan, bahkan di negara-negara maju seperti Amerika Serikat, bahwa pendidikan dalam perkuliahan di abad 20 lebih didominasi oleh kegiatan pendidikan bagi inovasi dan ekperimentasi, tetapi kurang dalam pengembangan dimensi tujuan dan kebutuhan aktual. Dominasi pencarian pengetahuan teknologis, lebih dominan dari pada pencarian idiologis yang lebih arif. Fenomena itu menunjukkan betapa pendidikan dalam perkuliahan telah bergeser dari penanaman dan pengembangan nilai-nilai demokrasi dalam proses belajar, kebebasan dalam mengembangkan potensi kemanusiaan dan penjalinan komunikasi yang sinergis antara dosen dan mahasiswanya. Ditambah lagi dengan kurang cermatnya kebijakan pendidikan tinggi dalam memahami mahasiswa sebagai manusia yang unik dan mandiri serta harus secara pribadi mempertanggung jawabkan tindakannya, menyebabkan perkuliahan akan berubah menjadi "pemasungan" daya kreatif individu. Penelitian Mikalachki menyarankan agar pendidik mengembangkan 
strategi kelas sesuai perhatian afeksinya. Belajar kognitif cenderung tidak peduli pada perasaan dan linkungan sosial. Menurutnya belajar kognitif tidak dapat dilakukan pada suasana yang tidak mendukung afeksi. Selama ini kampus-kampus lebih mementingkan kemampuan kognisi, daya nalar dan ketrampilan menjawab soal-soal ujian. Pendidikan nilai, kepribadian terutama untuk demensi afektif kurang mendapat perhatian (Mulkhan, 1993, p.17). Di samping masih kurangnya nilai-nilai kebebasan mahasiswa dalam berekpresi yang ada pada dirinya ketika mengikuti kegiatan proses perkuliahan baik di dalam kelas maupun di luar kelas.

Program aksi yang dilakukan untuk peningkatan mutu kampus secara konvensional selalu menekankan pada aspek peningkatan mutu proses perkuliahan, dan sedikit menyentuh menajemen kampus, dan kurang menyentuh aspek kbebasan individu dalam menemukan hal yang diinginkan (berinquiry).

\section{METODE PENELITIAN}

\section{A. Jenis Penelitian}

Jenis penelitian ini adalah penelitian deskriptif kualitatif dengan pendekatan fenomenologi, yaitu suatu pendekatan yang berusaha memahami makna perilaku manusia berdasarkan pemahaman, pemikiran para pelakunya (subyek yang diteliti) bukan pemikiran peneliti. Pendekatan fenomenologi menjadi pilihan dengan pertimbangan penelitian ini berupaya untuk mengungkap fenomena dalam proses perkuliahan yang bersifat inquiry di Politeknik Pertanian Negeri Samarinda.

\section{B. Tempat dan Waktu Penelitian}

Penelitian ini dilaksanakan di kampus Politeknik Pertanian Negeri Samarinda. Pada program studi yang ada mata kuliah dasar umum Bahasa Inggris 1 dan II dengan bobot 3 SKS. Penelitian dilaksanakan selama 6 (enam) bulan, dari awal September 2020 sampai dengan akhir Pebruari 2021.

\section{Subjek dan Objek Penelitian}

Mengingat proses perkuliahan merupakan kegiatan inti di dalam pengembangan potensi mahasiswa, maka peran stake-holders yang ada di kampus sangat menentukan keberhasilan pendidikan, maka dalam penelitian ini yang menjadi subyek penelitian adalah dosen pengampu mata kuliah Bahasa Inggris, mahasiswa, staf administrasi, pustakawan. Objek penelitian ini adalah situasi dan kondisi dalam proses perkuliahan praktek dalam bentuk project kepada mahasiswa, sehingga pelaksanaanya banyak di luar kelas. Dalam hal ini warga kampus sebagai pelaku, serta aktivitas yang dilakukan oleh warga kampus yang berkaitan dengan inquiry serta ekplorasi mahasiswa dalam mereka mengembangkan potensinya.

\section{Teknik dan Instrumen Pengumpulan Data}

Teknik pengumpulan data lebih banyak pada observasi berperanserta (participan observation), wawancara mendalam (in depth interview) dan dokumentasi (document review). Dalam penelitian ini yang menjadi instrumen penelitian adalah peneliti sendiri. Peneliti sebagai instrumen penelitian melaksanakan fungsi menetapkan fokus penelitian, memilih informan sebagai sumber data, melakukan pengumpulan data, menilai kualitas data, analisis data, menafsirkan data dan membuat kesimpulan atas temuannya.

\section{E. Keabsahan Data}

Dalam penelitian ini keabsahan data lebih bersifat sejalan seiring dengan proses penelitian berlansung. Keabsahan data dilakukan sejak awal pengambilan data, yaitu sejak melakukan reduksi data, display data dan penarikan kesimpulan atau verivikasi.

\section{F. Teknik Analisis Data}

Teknik analisis data menggunakan model analisis interaktif (Miles \& Huberman, 1984, p.20). Aktivitas dalam analisis data tersebut, meliputi: data reduction, data display, dan conclusion drawing/verification. Melalui upaya tersebut diharapkan dapat memperoleh jawaban atas permasalahan dalam penelitian ini.

\section{HASIL DAN PEMBAHASAN}

\section{A. Prinsip Dasar Perkuliahan yang Bersifat Inquiry}

Hasil penelitian menemukan beberapa prinsip dasar yang bersifat Inquiry dalam proses perkuliahan bagi siswa yaitu: 1. prinsip dasar dalam memelihara hubungan (caring relation), 2. prinsip dasar memberi kebebasan (freedom/Autonomy) dan 3. prinsip dasar demokrasi (Democracy).

\section{Prinsip Dasar dalam Memelihara Hubungan} (Caring Relationships)

Dalam perkuliahan yang bersifat inquiry, interaksi yang harmonis antara dosen dan mahasiswa di dalam kelas maupun di luar kelas sangat mempengarui keberhasilan upaya dalam mengembangkan potensi yang ada pada masingmasing individu. Memelihara hubungan merupakan sebuah konsep yang telah banyak dibahas oleh filsuf Amerika, Noddings (1984: 4). Menurut beliau bahwa pemeliharaan merupakan kondisi dasar dalam kehidupan manusia terhadap semua orang yang cinta dan berusaha. Menjaga hubungan, dia berpendapat, dimulai dengan ibu dan bayinya, yang intinya merupakan hubungan ibu dalam merespon karena cinta dan kecenderungan alami. Noddings (1984: 5), menambahkan bahwa secara garis besar, menjaga hubungan melibatkan cinta, rasa hormat, perhatian reseptif, perhatian, dan minat yang tulus pada yang lain.

Palmer (1983: 418), berpendapat bahwa hubungan yang penuh perhatian dan tulus adalah dibangun berdasarkan rasa keterhubungan kita membangun dengan yang lain (others). Rasa keterhubungan, beliau menambahkan, tergantung pada kemampuan kita untuk berhubungan kembali diri kita untuk diri kita lebih dalam. Dalam pandangan Palmer, pendidik yang terputus dari jiwa mereka tidak dapat terhubung dengan yang dididik mereka. Jika mereka tidak tahu siapa mereka, menurutnya, mereka tidak bisa memahami siapa learner mereka. Argumen 
Palmer ini bergema dalam karya John Miller, Richard Brown, dan Ratna Kessler, tiga pemimpin di bidang pendidikan holistik yang telah mendirikan holistik program pelatihan pendidik Ketiga pendidik telah menempatkan "hubungan jiwa" di jantung programs.

Pendidik holistik, mereka juga melihat hubungan yang positif dan penuh kasih sayang sebagai dasar bagi pendidikan seseorang. Mereka juga percaya bahwa untuk berkembang, learner perlu aman dalam lingkungan, di mana mereka merasa dicintai, dihormati, dipahami, dan diterima untuk dapat terungkap kualitas mereka dan capabilities. Steiner (1970: 36), misalnya, sangat bersikeras bahwa pengajar harus mencintai semua learners mereka tanpa syarat dan sepenuhnya menerima mereka masingmasing sebagai learner dia. Pendidikan, menurutnya, harus selalu didasarkan pada cinta terhadap learners, dan mengajar, mendidik harus mendekati pada berdasarkan pengalaman hidup. Pendidikan sebagai suatu tindakan kasih dan mendesak pengajar untuk mencoba memahami, menghormati, dan menerima individualitas setiap siswa, Montessori (1976: 27). Dia percaya learners membutuhkan pendidik yang peduli bekerja sama dengan mereka dan bukan tokoh otoriter bekerja pada mereka.

\section{Prinsip Dasar Memberi Kebebasan}

(Freedom/Autonomy)

Pengembangan potensi individu yang bersifat inquiry tentunya memerlukan situasi dan kondisi pembelajaran yang selalu memfasilitasi kebebasan dan otonomi individu baik di dalam kelas maupun di luar kelas. Kebebasan yang berarti bahwa setiap mahasiswa memiliki kebebasan berekpresi, kesempatan mengemukakan ide-ide mereka dan sebagainya tanpa mendapatkan tekanan dan rasa takut terhadap dosen. Menurut Lucila T. Rudge (Nakagawa, 2000) secara garis besar, dalam pendidikan holistik prinsip kebebasan /otonomi, yaitu: kebebasan yang memihak pada kebebasan batin, kebebasan berpikir, berekspresi, dan kebebasan bertindak. Pendidik holistik biasanya berkaitan dengan pencapaian kebebasan batin/rohani, dengan memberikan suasana yang memungkinkan kebebasan pikiran dan ekspresi dan pendidikan yang menumbuhkan kebebasan menentukan dan otonomi di dalam proses belajar. Masih berkenaan dengan kebebasan learners Drost dalam teori kemerdekaan learners mengungkapkan bahwa, orang tua dan pendidik perlu memberikan penghargaan terhadap kemerdekaan si learners. Kemerdekaan di sini hendaknya dipahami sebagai pembebasan learners dari paksaan material maupun spiritual (Drost, 1996:107).

Menurut Krishnamurti (1964: 12), ketika "terusmenerus bertanya, terus mengamati, dan terusmenerus belajar, "kita bisa" menemukan kebenaran. Cara lain untuk mengembangkan kebebasan batin yang menarik pemikir berbagai bidang holistik / pendidikan yang bersifat inquiry melindung learners dari rintangan eksternal, misal bahaya otoritas, penilaian, dan pendapat. Rousseau, misalnya, percaya bahwa menjaga learner dari tekanan dan ketidak jujuran dari "masyarakat beradab" sangat penting agar supaya manusia bebas. Konsen utamanya adalah dengan efek merusak dari penilaian orang dewasa dan pendapat atas penalaran learner. Bagi Rousseau (1979: 255), pikiran yang muda hanya akan berkembang dalam suasana kebebasan, bebas dari otoritas eksternal dan dari "nafsu dan pendapat manusia". Hanya dalam kebebasan, ia berpendapat, anak muda akan dapat melihat dengan matanya, merasa dengan hatinya, dan mengadili dengan pikirannya. Hanya dalam kebebasan ia akan dapat menjadi orang yang bebas, di mana "tidak ada otoritas akan mengatur dirinya di luar alasan itu sendiri."

Neill (1993), juga percaya bahwa melindungi laerners dari otoritas eksternal adalah penting untuk meningkatkan bebas secara individu. Menurutnya, menghormati otoritas dan dipaksa untuk disiplin moral selalu menyiratkan rasa takut, yang menghapus kemungkinan untuk kebebasan nyata. Di sekolahnya (Summerhill), Neill dicari untuk menyediakan lingkungan yang bebas dari otoritas apapun (baik itu disiplin, arah, saran, pelatihan moral, agama instruksi, dll) dan dari setiap harapan orang dewasa (menyesuaikan untuk menghindari). Dengan cara itu, ia percaya learners bisa memiliki kesempatan untuk menemukan diri mereka sendiri, untuk berpikir sendiri dan akhirnya menjadi diri sendiri.

Argumen lain dimiliki oleh sebagian besar pendukung kebebasan dalam pendidikan adalah bahwa belajar merupakan hasil dari suatu tindakan, bebas, sukarela, otonom dilakukan oleh learner itu sendiri dan tidak pernah produk dari teaching. Belajar asli seseorang, menurut mereka, hanya bisa muncul dari penemuan subject sendiri, pengalaman, dan kesimpulan. Pendidik berperan dalam suasana kebebasan biasanya mengambil bentuk fasilitator. Sebagian besar pendukung di wilayah beliau berpendapat bahwa dasar pendidik berfungsi untuk mengamati, membimbing, dan merangsang pertanyaan learners. Ini adalah learner yang memimpin jalannya, sementara pendidik di belakang dan mensupport. Singkatnya, pendidikan holistik barat membutuhkan pendidikan yang mempercayai melekat ke learners motivasi belajar dan potensi mereka untuk membuat pembelajaran terjadi: salah satu yang memberikan mereka kebebasan memilih dalam pengalaman belajar mereka, mendukung pertanyaan mereka (dengan pengajar sebagai fasilitator), mendorong mereka kemerdekaan dan otonomi, dan menempatkan mereka sebagai agen dalam proses pembelajaran.

\section{Prinsip Dasar Demokrasi (Democracy)}

Prinsip demokrasi merupakan elemen penting dalam pendidikan yang bersifat inquiry dalam proses pembelajaran. Dalam sistem demokrasi adanya sikap menghargai kerjasama, partisipasi terhadap kelompok, dalam berbagi pengambilan keputusan. Dalam demokrasi, individu harus belajar untuk menyesuaikan kebutuhan mereka untuk memenuhi 
kepentingan kelompok dan fleksibel untuk memenuhi tuntutan "situasi baru yang dihasilkan oleh bervariasi hubungan" menggunakan partisipasi bersama dan bersama dalam pengambilan keputusan, Dewey (1996: 86).

Sebuah pendidikan yang demokratis, Ron Miller (pendukung demokrasi di bidang pendidikan holistik) berpendapat memungkinkan orang muda "untuk mengalami atau mempraktikkan bermakna partisipasi dalam lembaga sosial di mana mereka yang paling erat terlibat". Suatu sekolah demokratis, ia menjalankan "tidak satupun yang memperlakukan learners seolah-olah mereka sudah dewasa," tapi satu yang mengajarkan mereka untuk terlibat dalam pemecahan masalah kolaboratif dan mempersiapkan mereka" untuk latihan rasa matang tanggung jawab sosial" Selain advokasi untuk "demokrasi partisipatif," pendidik holistik kontemporer juga disebut demokratis "terbuka, dan egaliter hubungan pengajarlearner, Miller (1993: 78-79).

\section{a) Perkuliahan Demokratis}

Pembelajaran demokratis yang merupakan ciri dari pendidikan yang bersifat inquiry, berarti yang harus terjadi adalah bagaimana pola-pola demokratis dalam proses pembelajaran. Dengan kata lain pembelajaran demokratis adalah pembelajaran yang direncanakan dengan konsep yang memungkinkan praktik dari proses pembelajaran demokratis itu terlaksana, seperti memberikan kesempatan kepada learners seluasluasnya untuk belajar, berfikir, bekerja, dan membiarkan mereka bergerak membangun keilmuannya, sehingga learner memiliki peluang yang besar untuk belajar memberanikan diri membuka wawasannya.

Dikemukakan oleh John I. Goodlad dalam buku yang berjudul "Paradigma Pendidikan Demokratis" bahwa terpenuhinya misi pendidikan sangat tergantung pada kemampuan pendidik untuk menanamkan setting demokrasi pada learners, dengan memberikan kesempatan seluasluasnya pada learners untuk belajar (Goodlad, 1996:113), yakni bahwa sekolah, menjadi tempat yang nyaman bagi siswa learners untuk semaksimal mungkin mereka belajar.

Jadi dari situ kita bisa membuka paradigma berfikir kita bahwasanya seorang learners belajar adalah untuk menambah khazanah keilmuan serta pengalaman belajar mereka, sehingga seorang pendidik dituntut benar-benar mampu mengembangkan strategi pembelajaran, agar tercapai tujuan dari proses pembelajaran.

Selain itu, suasana yang demokratis dalam kelas juga akan banyak memberikan kesempatan kepada learners untuk berlatih mewujudkan dan mengambangkan hak atau kemampuannya serta kewajibannya. Suasana yang demokratis dapat dikembangkan dalam proses pembelajaran melalui hubungan antara pendidik dengan murid. Dan dalam suasana demokratis, itu juga semua pihak memperoleh penghargaan sesuai dengan potensi dan prestasinya masing-masing, sehingga dapat memupuk rasa percaya diri dan dapat berkreasi sesuai dengan kemampuannya tersebut.

Dalam pembelajaran yang demokratis yang merupakan ciri dari proses pembelajaran yang mempunyai sifat inquiry, learners betul-betul sebagai subyek belajar, bukan sebagai botol kosong yang pasrah untuk diisi dengan berbagai ilmu oleh pendidik. Saat sekarang rasanya pembelajaran yang demokratis yang merupakan ciri pendidikan yang bersifat inquiry cukup mendesak untuk diimplementasikan di dalam kelas, setidaknya berdasarkan tiga alasan.

Pertama, kenyataan bahwa pendidik bukan lagi satu-satunya sumber belajar. Dalam era globalisasi informasi sekarang tidak bisa dipungkiri, akses terhadap berbagai sumber informasi menjadi begitu luas, televisi, radio, buku, koran, majalah, dan internet. Saat berada di kelas, learners telah memiliki seperangkat pengalaman, pengetahuan, dan informasi semua ini sesuai dengan bahan pelajaran, bisa juga bertentangan. Pembelajaran yang demokratis memungkinkan terjadinya proses dialog yang berujung pada pencapaian tujuan instruksional yang ditetapkan. Tanpa demokrasi di kelas, pendidik akan menjadi penguasa tunggal yang tidak dapat diganggu gugat. learners terkekang, dan akhirnya potensi kreativitasnya terbunuh.

Kedua, kompleksnya kehidupan yang dihadapi siswa setelah lulus. Masa depan menuntut mereka mampu menyesuaikan diri. Prinsip belajar yang relevan adalah belajar bagaimana belajar (learning how to learn). Artinya di kelas target pembelajaran bukan sekedar penguasaan materi, melainkan siswa harus belajar juga bagaimana belajar (secara mandiri) untuk hal-hal ini bisa terjadi apabila dalam kegiatan pembelajaran learners telah dibiasakan untuk berfikir sendiri, berani berpendapat, dan berani bereksperimen.

Ketiga, dalam konteks pendidikan demokrasi masyarakat, sebagai bagian dari anggota masyarakat, learners hendaknya sejak dini telah dibiasakan bersikap demokratis bebas berpendapat tetapi tetap dalam rule of game. Ini bisa dimulai di kelas dalam bentuk kegiatan pembelajaran yang menekankan adanya demokrasi. Pembelajaran yang demokratis merupakan pembelajaran yang di dalam implementasi praktisnya teraktualisasi interaksi dua arah antara pendidik dan learners. Guru dalam memberikan bahan pembelajaran selalu memberi kesempatan (opportunity) kepada siswa untuk aktif memberikan reaksi, siswa bisa bertanya ataupun memberi tanggapan yang kritis tanpa ada perasaan takut terhadap pendidik. Bahkan, kalau perlu learners diperbolehkan menyanggah informasi atau pendapat pendidik jika memang dia mempunyai informasi atau pendapat yang berseberangan. 
Hal tersebut di atas senada seperti yang diungkapkan oleh Syafarudin Dirwan Nasution, (2005 :129-130). Bahwa hasil belajar pada dasarnya merupakan hasil reaksi antara bahan pelajaran, pendapat pendidik, dan pengalaman learners sendiri. Dalam pembelajaran, learners betul-betul sebagai subyek belajar. Bukan diibaratkan sebagai botol yang kosong yang pasrah untuk diisi dengan berbagai ilmu oleh pendidik. Ketiga alasan di atas tampaknya cukup signifikan untuk memberikan rekomendasi tentang perlunya penerapan pembelajaran yang demokratis di kelas. Hanya saja, harus diakui ada beberapa kendala yang perlu diatasi. Dari pihak pendidik, kendala lebih bersifat psikologis. Bagaimanapun, selama ini pendidik telah tercitrakan sebagai orang yang serba tahu dan serba mampu. Pendidik memang harus berwibawa baik secara akademik maupun moral, namun mereka bukan berarti harus berlaku diktator dan otoriter. Harus ada perubahan paradigmanya, pendidik sekarang tidak harus serba tahu dan serba mampu karena hal itu memang mustahil. Yang penting, pendidik harus bisa menjadi fasilitator dan motivator sehingga mahasiswa dapat mengembangkan potensinya secara optimal. Untuk bisa mengubah paradigma ini, pendidik harus menyadari bahwa wibawa tidak akan lenyap dengan memberikan kesempatan kepada learner untuk mengembangkan kreativitas. Bukankah justru wibawa pendidik akan terangkat bila ia mampu menampilkan performa sebagai pendidik yang egaliter, bisa diajak diskusi, terbuka, dan demokratis. Sementara dari pihak learner, kendalanya adalah belum banyak keberanian untuk berpendapat. Selama ini mereka telah terkondisi untuk pasif, menerima apa pun informasi dari learner tanpa kritik. Kondisi ini harus diubah dengan cara mendorong mereka menyampaikan gagasan dan menghargainya. Apa pun pendapat learner, pendidik harus bisa memberikan apresiasi secara positif. Melalui penghargaan dan apresiasi secara positif terhadap learner, diharapkan berangsur-angsur learner terbiasa bersikap aktif dan berani mengemukakan pendapatnya di kelas. Berikut skema proses pembelajaran yang bersifat inquiry yang dilakukan oleh pendidik dalam kelas.

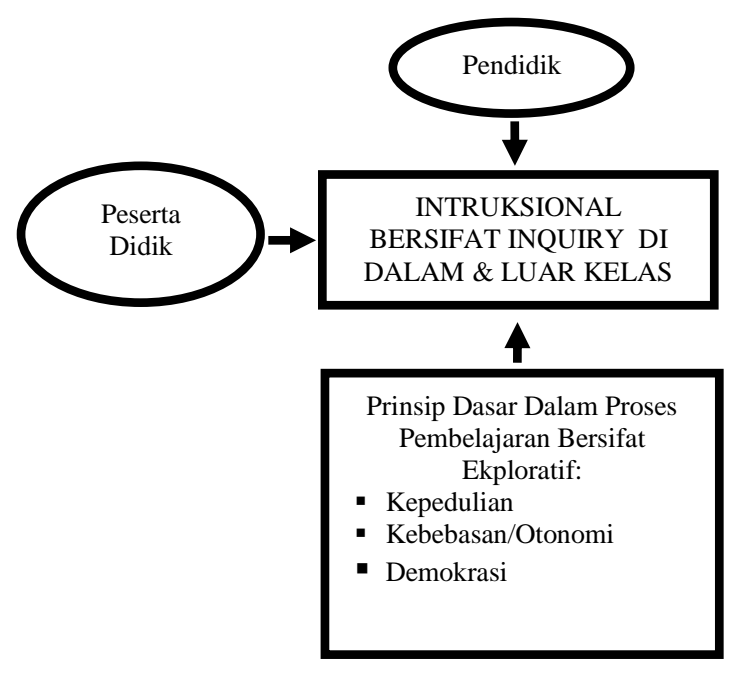

Gambar 1. Skema Proses Perkuliahan

\section{KESIMPULAN}

Bentuk pembelajaran yang bersifat inquiry, merupakan bentuk perkuliahan yang banyak memberikan kesempatan kepada mahasiswa untuk mengekplorasikan diri untuk mendapatkan pengetahuan dalam mengembangkan potensi yang ada pada diri mereka. Bentuk-bentuk inquiry yang ditemukan dalam penelitian ini yaitu: adanya bentuk menghargai hak kebebasan mahasiswa di dalam mengembangkan proses perkuliahan, dan esensi, bentuk demokrasi dalam proses perkuliahan yang ada pada diri mereka, dan bentuk caring relation atau bagaimana dosen memperlakukan mahasiswa dalam proses perkuliahan.

\section{DAFTAR PUSTAKA}

Dewey, J. (1996). Democracy and education. Clark, Designing and Implementing an Integrated Curriculum. New York: Todnam's Sons.

Drost, J. (1996). Universitas pusat belajar bernalar. Dalam Kadjat Hartono, Harry Tjan Silalahi, Hadi Soesastro (penyunting), Nalar dan Naluri: 70 Tahun Daoed Joesoef. Jakarta.

Krishnamurti, J. (1964). Think on these thing. New York: Harper \& Row.

Mansour, Fakih. et al. (2001). Pendidikan popular membangun kesadaran kritis. Yogyakarta: Insist.

Miller, J.P. (1976). Humanizing the classroom. New York: Praeger Publishers.

Miller, R. (1993). Philoshophical foundations. In holistic education principles. Perspectives

Miles, M.B., Huberman, A.M. (1984). Qualitative data analysis. Beverly Hills London New Delhi: Sage Publication.

Montessori, M.M. (1976). Education for human development: Understanding Montessori. New York: Schocken Books. 
Mulkhan, A.M. (1993). Paradigma intelektual muslim. Pengantar Filsafat Pendidikan dan Dakwah. Yogyakarta: Sipress.

Nasution, S. (2003). Azas-azas kurikulum. Jakarta: Bumi Aksara.

Neill, A. S., \& Albert Lamb. (1993). Summerhill school: A new view of childhood. New York.St: Martin's Press.

Noddings, N. (1984). Caring, a feminine approach to ethics and moral education. Berkeley, CA: University of California Press.

Palmer, J.A. (editor). (2003). 50 pemikir pendidikan. Dari Piaget sampai masa sekarang. (terjemahan : Farid Assifa). Yogyakarta: Penerbit Jendela.

Rousseau, J.J. (1979). Emile or on education. Translated by Allan Bloom. New York: Basic Books.Inc. Publishers.

Rudge, L. (2011), Holistic education : Varian model of education. Columbus, OHIO: College of Education and Human Ecology.

Steiner, R. (1970). The science of spirit, education and practical life." In education as an Art, edited by P. M. Allen, 50-83. Blauvelt, NY. Rudolf Steiner Publications.

Zamroni. (1992). Pengantar pengembangan teori social. Yogyakarta: Tiara Wacana.

Zuchdi, D. (2009). Humanisasi pendidikan. Jakarta. PT. Bumi Aksara. 